\title{
Cubane $\left\{\mathrm{Cu}_{4}{ }_{4}\right\}$ Cluster as a Precursor for the Preparation of a Mixed-Valent $\left\{\mathrm{Cu}^{\mathrm{II}}{ }_{12} \mathrm{Cu}_{2}{ }_{2}\right\} \mathrm{Core}^{* *}$
}

\author{
Arindam Mukherjee, Munirathinam Nethaji, and \\ Akhil R. Chakravarty*
}

Current interests in the chemistry of high-nuclearity transition-metal complexes draw from their utility in the emerging science of nanomaterials, ${ }^{[1]}$ as models for the multimetal active sites of metal-storage proteins, ${ }^{[2]}$ and as single molecule magnets (SMMs). ${ }^{[3,4]}$ In addition, such super-sized molecules often show a variety of supramolecular interactions..$^{[5]}$ The "self-assembly" process of generating a high-nuclearity cluster from a mono- or dimeric precursor generally involves low-dentate organic ligands.

Using a pentadentate Schiff base, $N, N^{\prime}$-(2-hydroxypropane-1,3-diyl)bis(acetylacetoneimine) $\left(\mathrm{H}_{3} \mathrm{~L}\right)$, we have been successful in isolating a discrete tetranuclear copper(II) cubane cluster $\left[\left\{\mathrm{Cu}^{\mathrm{II}}(\mathrm{HL})\right\}_{4}\right](\mathbf{1})$ which, unlike other clusters, has four pendant arms with eight donor sites (four imine nitrogen atoms and four hydroxy groups) available for binding to additional metal ions. Complex $\mathbf{1}$, as a "molecular octopus", is a new precursor for high nuclearity copper clusters. This complex on reaction with copper(II) perchlorate in presence of $\mathrm{KOH}$ forms an octanuclear copper(II) species

[*] A. Mukherjee, M. Nethaji, Prof. A. R. Chakravarty Department of Inorganic and Physical Chemistry Indian Institute of Science

Bangalore-560012 (India)

Fax: (+91) 80-3600-683

E-mail: arc@ipc.iisc.ernet.in

[***] We thank the Department of Science and Technology, Government of India, for financial support (Grant SP/S1/F-01/2000) and for the CCD facility. We also thank the Convenor, Bioinformatics Center, IISc, for database search.

(1) Supporting information for this article is available on the WWW under http://www.angewandte.org or from the author. 
$\left[\mathrm{Cu}_{8} \mathrm{~L}_{4}(\mathrm{OH})_{3}\right]\left(\mathrm{ClO}_{4}\right)$ that has already been prepared by us from a different reaction using a binuclear precursor. ${ }^{[6]}$ The same metal-driven self-assembly process under different reaction conditions leads to the formation of a new discrete tetradecanuclear mixed-valent complex $\left[\mathrm{Cu}^{\mathrm{II}}{ }_{12} \mathrm{Cu}_{2} \mathrm{~L}_{6}(\mathrm{OH})_{6}\right]$ $\left(\mathrm{ClO}_{4}\right)_{2}(2)$. Herein, we present the synthesis, crystal structures and magnetic properties of $\mathbf{1}$ and $\mathbf{2}$. Complex $\mathbf{2}$ is a rare discrete molecular tetradecanuclear transition-metal complex with multidentate ligand system. ${ }^{[7]}$ In addition two copper(I) atoms are encapsulated in a core containing twelve copper(II) atoms giving a prismatic propeller structure.

Complex $\left[\{\mathrm{Cu}(\mathrm{HL})\}_{4}\right](\mathbf{1})$, prepared from a reaction of $\left[\mathrm{Cu}\left(\mathrm{H}_{2} \mathrm{O}\right)_{6}\right]\left(\mathrm{ClO}_{4}\right)_{2}$ with $\mathrm{H}_{3} \mathrm{~L}$ in presence of triethylamine in $\mathrm{CH}_{2} \mathrm{Cl}_{2} / \mathrm{MeOH}$, crystallizes in the cubic space group $P \overline{4} 3 n$ with one copper center and one ligand along with one lattice water in the crystallographic asymmetric unit. ${ }^{[8]}$ The structure consists of a tetranuclear core with the metal centers linked by $\mu_{3}$ alkoxo oxygen atom, to form a cubic arrangement of the metal and the oxygen atoms (Figure 1). The copper centers

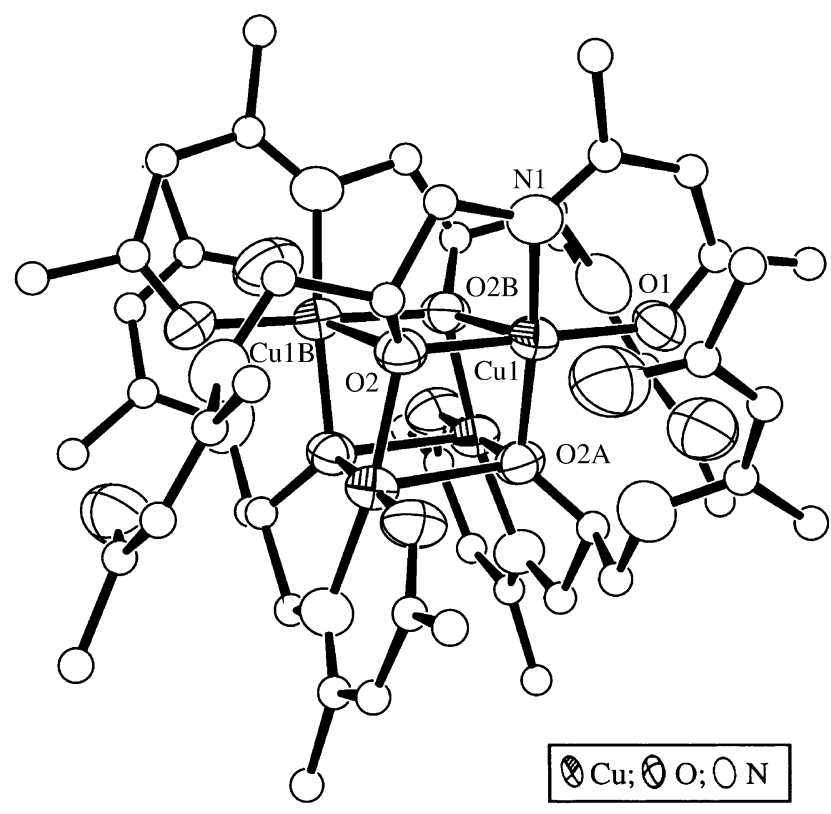

Figure 1. A perspective view of the complex in $\left(1.4 \mathrm{H}_{2} \mathrm{O}\right)$ the thermal ellipsoids are set at $50 \%$ probability, the carbon atoms are shown as spheres with a reduced size for clarity. Selected interatomic distances $[\AA ̊ A]$ and angles $\left[{ }^{\circ}\right]$ : Cu1-O1 1.905(6), Cu1-O2 1.974(5), Cu1-O2A 1.971 (5), Cu1-O2B 2.437(5), Cu1-N1 1.927(7); Cu1-O2-Cu1B 101.9(2), Cu1-O2-Cu1C 104.7(2), Cu1B-O2-Cu1C 89.61 (19). Symmetry operations: $\mathrm{A}:-x+3 / 2, z-1 / 2,-\gamma+1 / 2 ; \mathrm{B}: x,-\gamma,-z+1 ; \mathrm{C}:-x+3 / 2,-z+1 / 2$, $y+1 / 2$.

are in an essentially square-pyramidal $(4+1)$ geometry with one bridging $\mathrm{Cu}-\mathrm{O}$ bond being the axial group (2.437(5) $\AA$ ). The $\mathrm{Cu} \cdots \mathrm{Cu}$ distances are 3.438(1) and 3.124(1) $\AA$. The potentially pentadentate ligand $\left(\mathrm{H}_{3} \mathrm{~L}\right)$ binds in a dianionic tridentate form through one imine nitrogen, one enolized oxygen as the terminal, and the anionic alkoxo-oxygen atom as the bridging site. This leaves the remaining hydroxy group and the imine nitrogen atom as pendant, noncoordinating sites suitable for cluster expansion through metal-driven self- assembly process (Figure 2). The nonbonded shortest $\mathrm{Cu} \cdots \mathrm{O}$ and $\mathrm{Cu} \cdots \mathrm{N}$ separations involving the pendant donor sites are 3.6 and $3.2 \AA$, respectively.

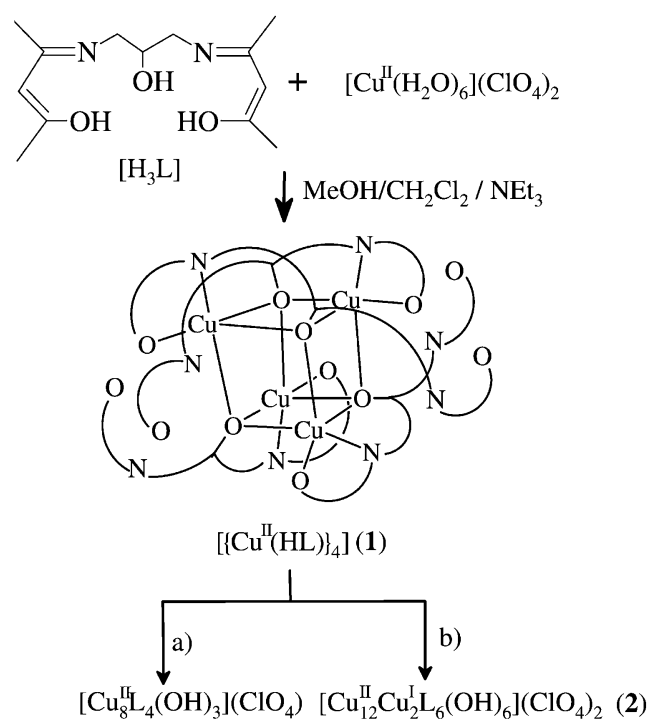

Figure 2. Reaction pathways in the self-assembly processes forming tetra-, octa-, and tetradecanuclear copper cores: a) $\left[\mathrm{Cu}\left(\mathrm{H}_{2} \mathrm{O}\right)_{6}\right]\left(\mathrm{ClO}_{4}\right)_{2}$ and $\mathrm{KOH}$ in $\mathrm{EtOH}$; b) $\left[\mathrm{Cu}\left(\mathrm{H}_{2} \mathrm{O}\right)_{6}\right]\left(\mathrm{ClO}_{4}\right)_{2}, \mathrm{H}_{3} \mathrm{~L}$, and piperidine in $\mathrm{CH}_{2} \mathrm{Cl}_{2} / \mathrm{MeOH}$.

When $\mathbf{1}$ is treated with $\left[\mathrm{Cu}\left(\mathrm{H}_{2} \mathrm{O}\right)_{6}\right]\left(\mathrm{ClO}_{4}\right)_{2}$ in a 1:4 molar ratio in presence of $\mathrm{KOH}$ in ethanol, the product is an octanuclear copper(II) complex $\left[\mathrm{Cu}_{8} \mathrm{~L}_{4}(\mathrm{OH})_{3}\right]\left(\mathrm{ClO}_{4}\right)$, that has already been reported by us. ${ }^{[6]}$ The reaction involves an addition of four copper(II) ions. Further addition of metal ions to 1 takes place on treatment of it with $\left[\mathrm{Cu}\left(\mathrm{H}_{2} \mathrm{O}\right)_{6}\right]\left(\mathrm{ClO}_{4}\right)_{2}$ and $\mathrm{H}_{3} \mathrm{~L}$ in a 1:10:4 mole ratio in presence of piperidine in methanol and $\mathrm{CH}_{2} \mathrm{Cl}_{2}$ to form the tetradecanuclear mixedvalent complex $\left[\mathrm{Cu}_{12}^{\mathrm{II}} \mathrm{Cu}_{2}^{\mathrm{I}} \mathrm{L}_{6}(\mathrm{OH})_{6}\right]\left(\mathrm{ClO}_{4}\right)_{2}$ (2). The cluster expansion process $\mathbf{1} \rightarrow \mathbf{2}$ involves the addition of ten copper atoms and two ligands to the cubane structure. Single crystals of $2 \cdot 3 \mathrm{H}_{2} \mathrm{O}$, obtained by slow evaporation of the reaction mixture, belong to the trigonal space group $R \overline{3} c$ with six molecules in the unit cell. ${ }^{[8]}$ The structure consists of six $\left\{\mathrm{Cu}_{2}{ }_{2} \mathrm{~L}\right\}^{+}$units, each linked to two $\mu_{3}-\mathrm{OH}$ groups attached to two copper(I) centers (Figure 3). The $\mathrm{N}_{2} \mathrm{O}_{3}$-donor Schiff base displays trianionic pentadentate mode of coordination. There are two central encapsulated copper(I) units that are presumably formed by the reduction of cupric ion owing to geometrical constraints within the core (see below). The $\mathrm{Cu} 3$ atom is bonded to three $\mathrm{OH}$ groups giving a threefold rotation axis with a propeller-shaped structure (see Supporting Information). In this essentially prismatic unit, the $\mathrm{Cu} 3$ atom has been assigned +1 oxidation state based on its trigonal-pyramidal structure in which the $\mathrm{Cu} 3-\mathrm{O} 4$ separation is 2.282(8) $\AA$. The $\mathrm{Cu} 3$ atom is displaced 1.27(1) $\AA$ from the plane formed by three hydroxo oxygen atoms. The $\mathrm{O}-\mathrm{Cu} 3-\mathrm{O}$ angle is $92.07(4)^{\circ}$. The deviation from the trigonal-planar structure could be due to the small size of the cavity accommodating the copper(I) atom. In addition, charge 


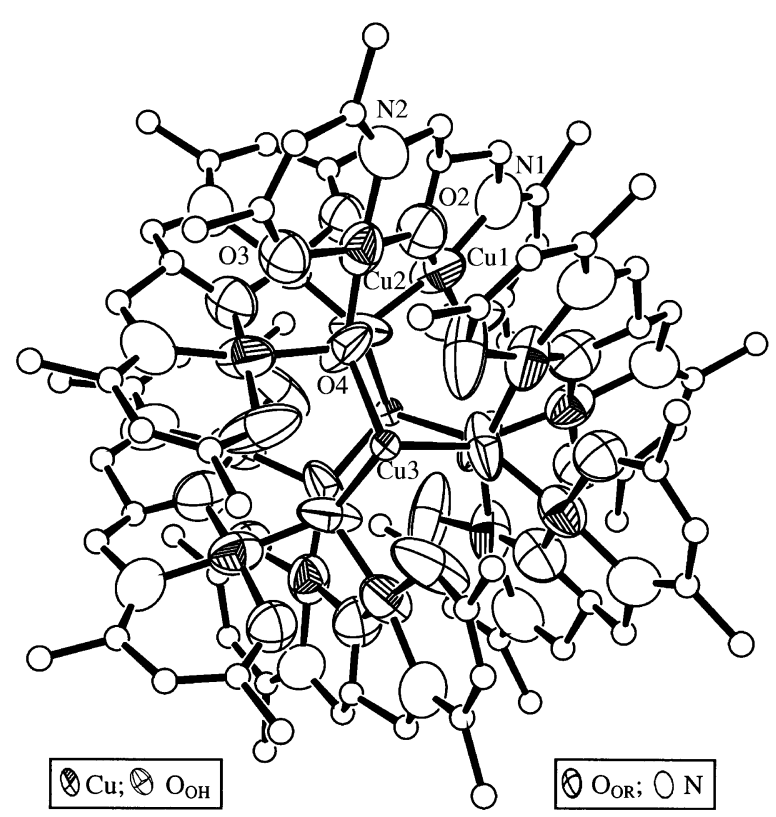

Figure 3. A perspective view of the complex in $2 \cdot 3 \mathrm{H}_{2} \mathrm{O}$ with the thermal ellipsoids set at $50 \%$ probability the carbon atoms are shown as spheres with a reduced size for clarity. Selected bond lengths $[\AA]$ and angles [ [ ]: Cu1-O1 1.899(11), Cu1-O2 1.941(11), Cu1-O4, 1.957(9), Cu2-O2 1.915(9), Cu2-O3 1.888(9), Cu2-O4 1.966(11), Cu1-N1 1.887(14), Cu2-N2 1.941(13), Cu3-O4 2.282(8); Cu1-O2-Cu2 136.5(6), Cu1C-O4-Cu2 101.8(4), Cu1C-O4-Cu3 100.4(4), Cu2-O4-Cu3 127.5(6). The prismatic structure involving the $\mathrm{Cu}^{\prime}$ centers can be seen. Symmetry operations: $\mathrm{C}:-x+y+2 / 3,-z+1 / 6,-x+4 / 3$.

neutrality of this discrete molecular species requires two copper centers in +1 oxidation state. The $\mathrm{Cu} \cdots \mathrm{Cu}$ distance of 3.583(3) $\AA$ within the $\left\{\mathrm{Cu}_{2} \mathrm{~L}\right\}^{+}$units in 2 is similar to that observed in $\left[\mathrm{Cu}_{2} \mathrm{~L}\left(\mathrm{O}_{2} \mathrm{CMe}\right)\right](3.502(2) \AA) .{ }^{[9]}$ The dicopper(II) units in 2 , however, resemble the dialkoxo-bridged dicopper(II) complexes. ${ }^{[10]}$

The cluster expansion process is associated with a significant change in the magnetic properties as shown by preliminary magnetic data. The temperature dependence of the magnetic susceptibility of $\mathbf{1}$ and $\mathbf{2}$ is shown in Figure 4. The cubane cluster 1 has a $\mu_{\text {eff }}$ value of $1.76 \mu_{\mathrm{B}}$ and $2.31 \mu_{\mathrm{B}}$ per copper(II) center at 300 and $18 \mathrm{~K}$, respectively ( $\mu_{\text {eff }}$ per molecule: $3.51 \mu_{\mathrm{B}}, 300 \mathrm{~K}$; $4.63 \mu_{\mathrm{B}}, 18 \mathrm{~K}$ ). The observed increase in the $\chi_{M} T$ value on lowering the temperature

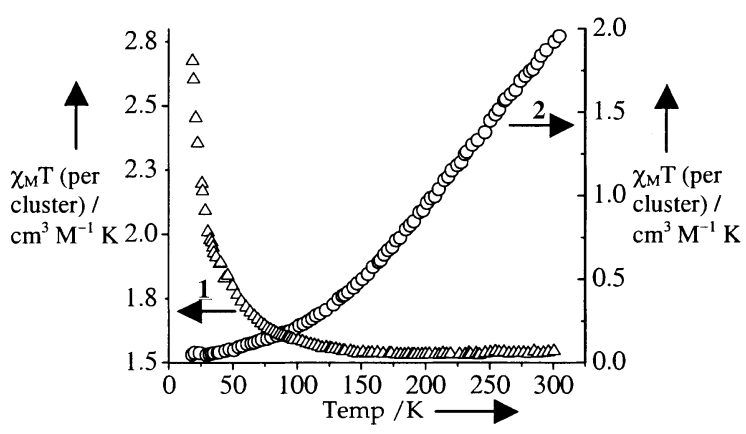

Figure 4. Plots of $\chi_{M} T$ (per molecule) versus $T$ for complexes $1(\triangle)$ and $2(O)$ in the temperature range $305-18 \mathrm{~K}$. suggests intracluster ferromagnetic interaction. ${ }^{[11]}$ The contribution from the intercluster magnetic interaction should be negligible considering the large separation of the clusters from each other (intercluster $\mathrm{Cu} \cdots \mathrm{Cu}$ separation, $\approx 9.5 \AA$ ). The tetradecanuclear complex 2 shows, in contrast, strong antiferromagnetic (AF) behavior with singlet as a ground state. The magnetic moment values per copper(II) center are 1.12 and $0.17 \mu_{\mathrm{B}}$ at 300 and $18 \mathrm{~K}$, respectively ( $\mu_{\text {eff }}$ per molecule: $3.91 \mu_{\mathrm{B}}, 300 \mathrm{~K}$; $0.62 \mu_{\mathrm{B}}, 18 \mathrm{~K}$ ). Complex 2 has six $\left\{\mathrm{Cu}_{2} \mathrm{~L}\right\}^{+}$moieties with a $\mathrm{Cu}-\mathrm{O}-\mathrm{Cu}$ alkoxo bridge angle of $137^{\circ}$. Such an angle with a planar geometry of the alkoxo oxygen atom is likely to promote strong AF interactions within the dimeric unit. ${ }^{[10]}$ The Cu1C-O4-Cu2 angle of $101.8(4)^{\circ}$ with a pyramidal geometry of $\mathrm{O} 4$ atom (sum of angles $330^{\circ}$ ) is likely to promote weak AF interactions between two intracluster interdimer units. ${ }^{[12]}$ Detailed magnetic studies are in progress.

In conclusion, the ferromagnetic cubane cluster 1 with eight pendant binding sites presents a reactive precursor for the synthesis of high-nuclearity copper clusters by metaldriven self-assembly processes. Isolation of discrete molecular octanuclear copper(II) and tetradecanuclear mixed-valent copper complex with a propeller-shaped $\left\{\mathrm{Cu}^{\mathrm{II}}{ }_{12} \mathrm{Cu}_{2}{ }_{2}\right\}$ core shows that the cubane complex can be used as a new precursor for the preparation of high-nuclearity clusters of nanometric size.

\section{Experimental Section}

1 was prepared from a reaction of $\left[\mathrm{Cu}\left(\mathrm{H}_{2} \mathrm{O}\right)_{6}\right]\left(\mathrm{ClO}_{4}\right)_{2}(2.96 \mathrm{~g}$, $8.0 \mathrm{mmol})$ with $\mathrm{H}_{3} \mathrm{~L}^{[9]}(3.79 \mathrm{~g}, 14.9 \mathrm{mmol})$ in $\mathrm{CH}_{2} \mathrm{Cl}_{2} / \mathrm{MeOH}$ mixture $(1: 1 \mathrm{v} / \mathrm{v}, 40 \mathrm{~mL})$ in presence of triethylamine $(3.9 \mathrm{~mL}, 28.03 \mathrm{mmol})$ under reflux for $30 \mathrm{~min}$. Dark blue crystalline product in $\approx 87 \%$ yield was obtained on slow evaporation of the solvent at $25^{\circ} \mathrm{C}$. Single crystals were obtained by slow diffusion of hexane to a $\mathrm{CH}_{2} \mathrm{Cl}_{2}$ solution of 1 . Complex 2 was prepared in $\approx 66 \%$ yield from a reaction of $\mathbf{1}(0.2 \mathrm{~g}, 0.16 \mathrm{mmol})$ in $\mathrm{CH}_{2} \mathrm{Cl}_{2}(10 \mathrm{~mL})$ with $\left[\mathrm{Cu}\left(\mathrm{H}_{2} \mathrm{O}\right)_{6}\right]$ $\left(\mathrm{ClO}_{4}\right)_{2}(0.6 \mathrm{~g}, 1.6 \mathrm{mmol})$ in presence of $\mathrm{H}_{3} \mathrm{~L}(0.19 \mathrm{~g}, 0.64 \mathrm{mmol})$ and piperidine $(0.15 \mathrm{~mL}, 1.5 \mathrm{mmol})$ in $\mathrm{MeOH}(10 \mathrm{~mL})$. The octanuclear complex $\left[\mathrm{Cu}_{8} \mathrm{~L}_{4}(\mathrm{OH})_{3}\right]\left(\mathrm{ClO}_{4}\right)$ was prepared from a reaction of $\mathbf{1}$ $(0.21 \mathrm{~g}, 0.16 \mathrm{mmol})$ with $\left[\mathrm{Cu}\left(\mathrm{H}_{2} \mathrm{O}\right)_{6}\right]\left(\mathrm{ClO}_{4}\right)_{2}(0.24 \mathrm{~g}, 0.64 \mathrm{mmol})$ and $\mathrm{KOH}(0.53 \mathrm{~g}, 0.94 \mathrm{mmol})$ in ethanol $(15 \mathrm{~mL})$ in $55 \%$ yield $(0.14 \mathrm{~g})$. The crystals of the octanuclear complex gave cell parameters similar to those reported earlier. ${ }^{[6]}$ Elemental analysis (\%) calcd for 1: C 49.44, H 6.38, N 8.87; found C 49.21, H 6.54, N 9.02, (\%) calcd for 2 C 34.72, $\mathrm{H} 4.48, \mathrm{~N} 6.23$; found: $\mathrm{C} 34.88, \mathrm{H} 4.68, \mathrm{~N} 6.33$. UV/Vis in $\left.\mathrm{MeOH} \lambda_{\text {max }},\left(\varepsilon, \mathrm{M}^{-1} \mathrm{~cm}^{-1}\right)\right]: 233$ (22500), 310 (43000), $630 \mathrm{~nm}$ (280) for 1 and 281 (60000), 315 (91000), $620 \mathrm{~nm}$ (1000) for 2. $\chi_{\mathrm{M}} T$ (per molecule $\mathrm{cm}^{3} \mathrm{M}^{-1} \mathrm{~K}: 2.675$ at $18.54 \mathrm{~K}$ and 1.551 at $305.31 \mathrm{~K}$ for $\mathbf{1}$; 0.048 at $18.41 \mathrm{~K}$ and 1.954 at $304.73 \mathrm{~K}$ for $\mathbf{2}$ (Supporting Information).

Received: July 10, 2003 [Z52350]

Keywords: cluster compounds - copper - magnetic properties . mixed-valent compounds · self-assembly

[1] R. E. P. Winpenny, Adv. Inorg. Chem. 2001, 52, 1; V. G. Makhankova, O. Y. Vassilyeva, V. N. Kokozay, B. W. Skelton, J. Reedijk, G. A. Vanalbada, L. Sorace, D. Gatteschi, New. J. Chem. 2001, 25, 685 .

[2] H. Oshio, N. Hoshino, T. Ito, M. Nakano, F. Renz, P. Gütlich, Angew. Chem. 2003, 115, 233; Angew. Chem. Int. Ed. 2003, 42, 
223; A. Caneschi, A. Cornia, S. J. Lippard, Angew. Chem. 1995, 107, 511; Angew. Chem. Int. Ed. Engl. 1995, 34, 467.

[3] D. Gatteschi, R. Sessoli, Angew. Chem. 2003, 115, 278; Angew. Chem. Int. Ed. 2003, 42, 268.

[4] W. Wernsdorfer, N. Aliaga-Alcalde, D. N. Hendrickson, G. Christou, Nature 2002, 416, 408.

[5] J.-M. Lehn in Supramolecular Chemistry - Concepts and Properties, VCH, Weinheim, 1995; R. W. Saalfrank, E. Uller, B Demleitner, I. Bernt, Struct. Bonding (Heidelberg) 2000, 96 , 149; F. A. Cotton, C. Lin, C. A. Murillo, Acc. Chem. Res. 2001 34, 759; M. Fujita, K. Umemoto, M. Yoshizawa, N. Fujita, T. Kusukawa, K. Biradha, Chem. Commun. 2001, 509; G. J. E. Davidson, S. J. Loeb, Angew. Chem. 2003, 115, 78; Angew. Chem. Int. Ed. 2003, 42, 74; B. J. Holliday, C. A. Mirkin, Angew. Chem. 2001, 113, 2076; Angew. Chem. Int. Ed. 2001, 40, 2022.

[6] K. Geetha, M. Nethaji, A. R. Chakravarty, Inorg. Chem. 1997, $36,6134$.

[7] C. J. Milios, E. Kefalloniti, C. P. Raptopoulou, A. Terzis, R Vincete, N. Lalioti, A. Escuer, S. P. Perlepes, Chem. Commun. 2003, 819; G. Aromi, A. Bell, S. J. Teat, A. G. Whittaker, R. E. P. Winpenny, Chem. Commun. 2002, 1896.

[8] Crystal data for $\mathbf{1} \cdot 4 \mathrm{H}_{2} \mathrm{O}: \mathrm{C}_{52} \mathrm{H}_{88} \mathrm{~N}_{8} \mathrm{O}_{16} \mathrm{Cu}_{4}, M_{\mathrm{r}}=1335.46$, blue prisms $(0.265 \times 0.18 \times 0.145 \mathrm{~mm})$, cubic, $P \overline{4} 3 n, \quad a=b=c=$ 22.421(4) ̊, $V=11272(3) \AA^{3}, Z=6, \rho_{\text {calcd }}=1.180 \mathrm{~g} \mathrm{~cm}^{-3}, \mu=$ $1.174 \mathrm{~mm}^{-1}, \mathrm{~min} / \mathrm{max}$ trans. $=0.6341 / 0.8345,2 \theta_{\max }=48^{\circ}, \lambda($ Mo$\mathrm{K} \alpha)=0.71073 \AA, \quad T=293(2) \mathrm{K}, 2961$ unique reflections $[R($ int $)=0.1554], R 1=0.0693, w R 2=0.1805[I>2 \sigma(I)], R 1=$ $0.0953, w R 2=0.1915$ (all data), $\operatorname{GoF}\left(F^{2}\right)=1.077, N_{0} / N_{\mathrm{v}}=2960 /$ 180. Crystal data for $2 \cdot 3 \mathrm{H}_{2} \mathrm{O}: \mathrm{C}_{78} \mathrm{H}_{126} \mathrm{~N}_{12} \mathrm{O}_{35} \mathrm{Cl}_{2} \mathrm{Cu}_{14}, M_{\mathrm{r}}=$ 2752.37 , green prisms $(0.325 \times 0.185 \times 0.09 \mathrm{~mm})$, trigonal, $R \overline{3} c$, $a=b=16.318(2), c=70.22(2) \AA, V=16193(6) \AA^{3}, Z=6, \rho_{\text {calcd }}=$ $1.693 \mathrm{~g} \mathrm{~cm}^{-3}, \quad \mu=2.824 \mathrm{~mm}^{-1}, \min / \max$ trans. $=0.6133 / 0.8943$ $2 \theta_{\max }=50^{\circ}, \lambda(\mathrm{Mo}-\mathrm{K} \alpha)=0.71073 \AA, T=293(2) \mathrm{K}, 3077$ unique reflections $[R($ int $)=0.0781], R 1=0.0879, w R 2=0.2634[I>$ $2 \sigma(I)], R 1=0.1228, w R 2=0.2908$ (all data), $\operatorname{GoF}\left(F^{2}\right)=1.048$, $N_{0} / N_{\mathrm{v}}=3077 / 205$. X-ray diffraction data were measured in frames with increasing $\omega$ (width of $0.3 \mathrm{deg}$./frame) and with a scan speed at $6 \mathrm{~s} /$ frame for $\mathbf{1}$ and at $12 \mathrm{~s} /$ frame for $\mathbf{2}$ on a Bruker SMART APEX CCD diffractometer, equipped with a fine focus $1.75 \mathrm{~kW}$ sealed tube X-ray source. Empirical absorption corrections were carried out using MULTISCAN (for 1) and SADABS (for 2) program: R. Blessing, Acta Crystallogr. Sect. A 1995, 51, 33. The structures were solved by the heavy atom method and refined by full matrix least-squares using SHELX system of programs: G. M. Sheldrick, SHELXS-97, Program for the Solution of Crystal Structures, University of Göttingen, Göttingen (Germany), 1997. All non-hydrogen atoms were refined anisotropically. The hydrogen atoms attached to carbon atoms in the complex were generated and assigned isotropic thermal parameters, riding on their parent carbon atoms, and used for structure factor calculation only. CCDC 214522 and 214523 contain the supplementary crystallographic data for $\mathbf{1}$ and $\mathbf{2}$, respectively. These data can be obtained free of charge via www.ccdc.cam.ac.uk/conts/retrieving.html (or from the Cambridge Crystallographic Data Centre, 12 Union Road, Cambridge CB21EZ, UK; fax: (+44)1223-336-033; or deposit@ ccdc.cam.ac.uk). ORTEP and packing diagrams in color for $\mathbf{1}$ and $\mathbf{2}$ are given as Supporting Information.

[9] Y. Nishida, S. Kida, J. Chem. Soc. Dalton Trans. 1986, 2633.

[10] M. Handa, N. Koga, S. Kida, Bull. Chem. Soc. Jpn. 1988, 61, 6853.

[11] H. Oshio, Y. Saito, T. Ito, Angew. Chem. 1997, 109, 2789; Angew. Chem. Int. Ed. Engl. 1997, 36, 2673.

[12] O. Kahn, Molecular Magnetism, VCH, Weinheim, 1993. 